\title{
Religiøs mestring i medisinsk behandling
}

\author{
Kunnskap om medisin og humanisme er viktig i medisinsk behandling. Kartlegging av pasientens mestrings- \\ ressurser og det å understøtte disse i behandlingsforløpet er helsefremmende. Et religiøst mestrings- \\ perspektiv kan være en integrert del av denne prosessen.
}

Pasientens religiøse tro kan være relevant i den medisinske behandlingen. Å ta opp en religiøs anamnese kan være nyttig, særlig når pasienten er alvorlig syk og har begrenset forventet levetid eller har kronisk sykdom med sterkt plagsomme symptomer (1). Legen Peter F. Hjorts (1924-2011) tenkning om behandling kan være egnet som utgangspunkt for en slik praksis (2).

Behandlerens to bein må være like lange - biomedisinsk fagkunnskap og humanistisk menneskekunnskap. Legen må kunne sitt fag for å kunne ta gode avgjørelser. Vel så viktig, ifølge Hjort, er behandlerens menneskekunnskap og evne og vilje til å bli kjent med pasienten. Sammen kan disse komponentene skape konstruktiv kommunikasjonen med pasienten, inngi trygghet og legge til rette for gode behandlingsvalg. Dette kan gi en ikke ubetydelig placeboeffekt og bedre selvopplevd helse på tross av mye plager og alvorlig sykdom.

\section{Mestring}

I samspillet mellom behandler og pasient er kartlegging av pasientens mestringsevner nødvendig for å kunne gi adekvat støtte $\mathrm{i}$ behandlingsprosessen. Disse er særlig knyttet til håp og optimisme, ivaretakelse av selvbilde, omsorg for andre, aktiviteter som gir glede og bruk av kroppen. Dette er kjente faktorer knyttet til selvopplevd helse og livskvalitet $(3,4)$.

Disse faktorene gjenfinnes i religiøs mestringsteori utarbeidet av blant andre den amerikanske religionspsykologen Kenneth Pargament (5).

\section{Religiøs mestring}

Religiøs mestring forstås av Pargament som multidimensjonell og prosessuell, og han vektlegger hvordan religiøsitet kan benyttes som mestringsressurs (5). Bruk av religiøse mestringsstrategier kan gi allmennmenneskelige gevinster som opplevelse av mening, følelsesmessig trøst, personlig kontroll, nærhet til andre eller bedre selvopplevd helse. Dette er hva Pargament kaller «en søken etter det betydningsfulle, relatert til det hellige» (5). De religiøse mestringsaktivitetene kan være både kollektivt og individuelt orientert. De vanligste er bønn, meditasjon, deltakelse i gudstjenester eller i fellesskap med en religiøs overbygning etc.

Religiøs mestring innebærer to psykologiske hovedprosesser: bevaring og endring.
$\AA$ bevare det som er betydningsfullt, er et naturlig førstevalg. Hvis de tilgjengelige religiøse mestringsaktivitetene ikke er tilstrekkelige for bevaring, endres oppmerksomheten til hvilke nye mestringsaktiviteter som kan tas i bruk. Det kan også være aktuelt å vurdere nye mål for mestringen. Dersom endringsprosessen er vellykket, skifter fokus til bevaring igjen, men nå til bevaring av de nye midlene og målene. Religiøs mestring kan være både positiv (hjelpsom) og negativ (uhjelpsom).

Religiøs mestringsteori har møtt betydelig vitenskapelig interesse de siste 20 årene (6). Teorien egner seg godt $i$ helserelaterte sammenhenger, også klinisk, fordi den er rettet inn mot bruk av religiøsitet til å mestre ikke-religiøse formål.

\section{Kliniske vurderinger}

En behandlingstilnærming basert på menneskekunnskap generelt og bevissthet omkring pasientens religiøse mestring spesielt bør diskuteres kritisk. Hvordan kan en pasient møtes med respekt på et område som regnes blant de aller mest private? Hva er behandlerens kompetanse i dette feltet? Hva er profesjonalitet i slike tilfeller?

En stor andel norske pasienter er religiøst aktive på måter som sammenfaller med religiøs mestringsteori (7). Det er grunn til å tro at åpenheten omkring religiøse spørsmål er blitt større i det norske samfunnet, også innen helseforskningen (8).

Det er avgjørende at behandleren kartlegger hvilke av pasientens iboende ressurser det kan investeres i (9). Behandleren kan ikke skaffe seg kunnskap om disse hvis han/hun ikke spør. Dette gjelder også pasientens religiøse mestringsressurser. Det er pasienten som har kompetansen og kjenner sine egne erfaringer om positive og negative sider av mestring. Behandlerens kompetanse handler i stor grad om hva han/ hun skal spørre om og hvordan. Pasienten må støttes på de positive mestringsressursene og få hjelp til å unngå de negative. Tverrfaglig samarbeid kan være nødvendig.

Det er mulig for en behandler å vurdere de religiøse aspektene ved mestring og understøtte disse «selv om vi ikke har fått «troens gave»»», som Peter F. Hjort uttrykker det (10). Først og fremst er det et spørsmål om en åpen holdning overfor pasienten og hans eller hennes kompetanse omkring egne ressurser og behov.

\author{
Torgeir Sørensen \\ torgeir.sorensen@mf.no \\ Det teologiske Menighetsfakultet \\ Tor Torbjørnsen \\ Lambertseter alders- og sykehjem
}

\begin{abstract}
Torgeir Sørensen (f. 1969) er teolog og pastoralkliniker. Han er stipendiat i religion og helse, Det teologiske Menighetsfakultet og Religionpsykologisk senter, Sykehuset Innlandet. Ingen oppgitte interessekonflikter.
\end{abstract}

Tor Torbjørnsen (f. 1946) er teolog og pastoralkliniker. Han er sykehusprest og stipendiat i klinisk religionspsykologi, Det teologiske Menighetsfakultet og Religionspsykologisk senter, Sykehuset Innlandet. Ingen oppgitte interessekonflikter.

\section{Litteratur}

1. Magelssen M, Fredheim OMS. En åndelig dimensjon er viktig for mange pasienter. Tidsskr Nor Legeforen 2011; 131: 138-40.

2. Hjort PF. Noe var bedre før - hvordan kan vi ta vare på det? Tidsskr Nor Lægeforen 2001; 121: 2069-72.

3. Antonovsky A. Hälsans mysterium. Stockholm: Natur och Kultur, 1991

4. Lazarus RS. Stress og følelser - en ny syntese. København: Akademisk forlag, 2006.

5. Pargament K. The psychology of religion and coping. New York, NY: The Guilford Press, 1997.

6. Koenig HG, McCollough ME, Larson DB. Handbook of religion and health. New York, NY: Oxford University Press, 2001.

7. Botvar PK. Endringer i nordmenns religiøse liv. I: Botvar PK, Schmidt U, red. Religion i dagens Norge. Oslo: Universitetsforlaget, 2010.

8. Helseundersøkelsen i Nord-Trøndelag (HUNT), HUNT 3. Spørreskjema. www.ntnu.no/c/ document_library/get_file?uuid $=59251 \mathrm{eca}-90 \mathrm{df}-$ 4eb8-86d4-06db64717349\&groupld=10304 (2.2.2011).

9. Pargament K. Spiritually integrated psychotherapy. Understanding and addressing the sacred. New York, NY: Guilford Press, 2007

10. Hjort PF. Pleie og omsorg ved livets slutt. I: Kirkevold M, Brodtkorp K, Ranhoff AH, red. Geriatrisk sykepleie. Oslo: Gyldendal Akademisk, 2008: 454-5.

Mottatt 3.2. 2111, første revisjon innsendt 1.3. 2011, godkjent 10.3. 2011. Medisinsk redaktør Petter Gjersvik. 